\title{
Use of FT-IR Spectra and PCA to the Bulk Characterization of Cell Wall Residues of Fruits and Vegetables Along a Fraction Process
}

\author{
Monika Szymanska-Chargot • Artur Zdunek
}

Received: 9 May 2012 / Accepted: 6 December 2012 /Published online: 27 December 2012

(C) The Author(s) 2012. This article is published with open access at Springerlink.com

\begin{abstract}
This study focuses on the analysis of polysaccharide residues from the cell walls of fruits and vegetables: tomato, potato, pumpkin, carrot and celery root. An alcoholinsoluble residue was prepared from plant material by extraction using the hot ethyl alcohol method and then cell wall fractions soluble in trans-1,2-diaminocyclohexane-N, $\mathrm{N}, \mathrm{N}^{\prime}, \mathrm{N}^{\prime}$-tetraacetate, sodium carbonate and alkaline solution were sequentially extracted. Infrared spectroscopy combined with Fourier transform (FT-IR) was used to evaluate differences among cell wall residues and among species after each step of sequential extraction of pectins and hemicelluloses. Additionally, pectic substances were identified using an Automated Wet Chemistry Analyser. Principal component analysis (PCA) was applied to FT-IR spectra in two regions: $1,800-1,200 \mathrm{~cm}^{-1}$ and $1,200-800 \mathrm{~cm}^{-1}$ in order to distinguish different components of cell wall polysaccharides. This method also allowed us the possibility of highlighting the most important wavenumbers for each type of polysaccharide: $1,740,1,610$ and $1,240 \mathrm{~cm}^{-1}$ denoting pectins or 1,370 and $1,317 \mathrm{~cm}^{-1}$ denoting hemicelluloses and cellulose, respectively.
\end{abstract}

Keywords FT-IR spectroscopy $\cdot$ Vegetable and fruit cell walls $\cdot$ Principal component analysis $\cdot$ Pectin $\cdot$ Hemicellulose

\author{
Abbreviations \\ C Cellulose \\ CDTA Trans-1,2-Diaminocyclohexane-N,N,N',N'- \\ tetraacetate \\ CWM Cell wall material
}

M. Szymanska-Chargot $(\bowtie) \cdot$ A. Zdunek

Department of Microstructure and Mechanics of Biomaterials, Institute of Agrophysics, Polish Academy of Science,

Doswiadczalna 4,

20-290 Lublin, Poland

e-mail: m.szymanska@ipan.lublin.pl $\begin{array}{ll}\text { FT-IR } & \text { Fourier transform infrared } \\ \text { P } & \text { Pectins } \\ \text { PC } & \text { Principal component } \\ \text { PCA } & \text { Principal component analysis } \\ \text { XG } & \text { Xyloglucan }\end{array}$

\section{Introduction}

The primary cell wall of fruits and vegetables mainly consists of various polysaccharides: pectins, hemicelulloses and cellulose, and comparably smaller amounts of structural glycoproteins, phenolic esters, minerals and enzymes [1, 2]. In the commonly accepted model of a plant cell wall, cellulose fibrils are embedded in matrix polysaccharides, which are pectins and hemicelluloses. Concentrations of each constituent vary according to the origin of the plant, the organs and the tissue [3]. Plant cell walls and their constitutive polysaccharide networks are vital with regard to the mechanical properties of the plant organ, such as stiffness or strength. In addition, the amount and structure of cell wall non-cellulosic polysaccharides changes during development and ripening, and again during senescence of fruit. During development and ripening, changes of cell wall properties are the result of compounds' synthesis, whereas during post-harvest rather dominates degradation. Modifications of non-cellulosic polysaccharides also have a tremendous effect on structure and arrangement of cellulose microfibrils and hence on the mechanical properties of cell wall and plant tissue [3].

Infrared spectroscopy is one of the most frequently used spectroscopic techniques for studying plant cell wall material. The main advantage of this method is high sensitivity. Additionally, combination with Fourier transform (FT-IR) has provided a very rapid, versatile and relatively inexpensive tool for compounds' identification. Transmission mode, 
attenuated total reflectance (ATR), diffusive reflectance and microspectroscopy are the most common among infrared spectroscopy methods [4, 5]. Among these techniques, ATR is a very convenient sampling method, which doesn't require sample heating, pressing or grinding [6]. This method enables saving time and avoiding treatment that could lead to undesired structural changes of the sample.

The middle region (wavenumbers from $4,000 \mathrm{~cm}^{-1}$ to $400 \mathrm{~cm}^{-1}$ ) of the infrared radiation is most widely used in the study of biological objects [5-7]. The infrared absorption spectrum of each compound has its own unique pattern in the range from $1,400 \mathrm{~cm}^{-1}$ to $400 \mathrm{~cm}^{-1}$, often called the fingerprint region [8]. Additionally, the region from $1,800 \mathrm{~cm}^{-1}$ to $1,400 \mathrm{~cm}^{-1}$ could deliver information about functional groups occurring in investigated molecules. Infrared spectroscopy, as a very fast technique, has found application in carbohydrates' investigation, especially for cell wall polysaccharides with the large diversity of pectins, hemicelluloses and cellulose. The polysaccharides show specific positioning and intensity of bands on the FT-IR spectra, therefore analysis of the 1,800$400 \mathrm{~cm}^{-1}$ region provides the possibility of specific carbohydrate recognition $[5,8]$.

Cellulose, which is an unbranched $\beta(1,4)$-linked glucan chain, is one of the most widely investigated polysaccharides. Pure cellulose exists in several crystalline polymorphs with different packing arrangements, which are known as cellulose I, II, III and IV. Cellulose I, which is the most abundant in nature, is a mixture composed of two distinct crystalline phases, cellulose $\mathrm{I}_{\alpha}$ and $\mathrm{I}_{\beta}$, which have the same

Fig. 1 Steps of plant material extraction conformations, but differ in crystal structure-having triclinic $\left(\mathrm{I}_{\alpha}\right)$ and monoclinic unit cells $\left(\mathrm{I}_{\beta}\right)$. By means of infrared spectroscopy, both conformation changes accompanying the transition from cellulose I to cellulose III polymorph and identification of allomorphic type cellulose $I_{\alpha}$ or $I_{\beta}$ [9-12] have been observed. The hemicelluloses and pectins are a large family of cell wall compounds. The role of pectin and hemicelluloses is to bind to cellulose microfibrils in cell walls. Among the large variety of hemicelluloses, plant primary cell walls consist of xyloglucans and glucomannans, which are replaced by arabinoxylans in grass and cereal cell walls [13]. Xyloglucan coats the cellulose microfibrils, attaching to their surface as well as between microfibrils, limiting their aggregation. Absorption of xyloglucan on cellulose microfibrils is practically the same in the presence of low concentrations of pectin as in their absence. On the other hand, in the case of the presence of pectin, an increase of xyloglucan concentration causes a decrease of pectin absorption onto cellulose. The cellulose-pectin interaction seems to be weaker than the cellulose-xyloglucan interaction [14]. Pectin is believed to form an independent network, which works as a plasticizer and water binding agent $[14,15]$. Pectins consist of compounds made up of a backbone of linear $(1,4)$-linked $\alpha$-D-galacturonan and side chains mainly of $\alpha$-D-galactopyranose, $\alpha$-L-arabinofuranose and $\alpha-(1,2)$ linked rhamnopyranosyl residue [5, 16-18].

The infrared investigation of pectic derivatives allows for the possibility of determining some functional groups which occur in pectic compounds [19]. Exploration of region $1,800-1,600 \mathrm{~cm}^{-1}$ offers the possibility of esterification
FRESH TISSUE
Extraction with hot alcohol method

Extraction with hot alcohol method

CELL WALL MATERIAL (CWM)

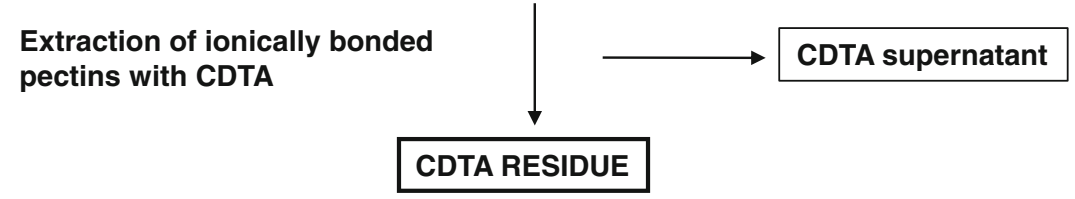

Extraction of covalently bonded pectins with $\mathrm{Na}_{2} \mathrm{CO}_{3}$

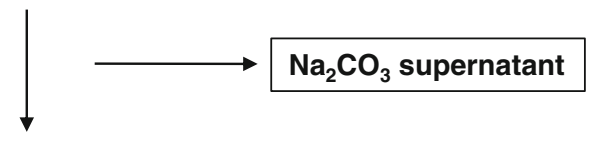

$\mathrm{Na}_{2} \mathrm{CO}_{3}$ RESIDUE

Extraction of hemicelluloses with $\mathrm{KOH}$

KOH RESIDUE 
degree estimation [20, 21]. Wellner et al. observed infrared band shift when investigating the interaction of divalent cations with potassium pectate, indicating a metal coordination by pectate [22]. Infrared spectroscopy of main hemicellulosic compounds covers identification of their specific bands and assignment of the monosaccharides constituting these compounds [5].

FT-IR has found application in monitoring of cell wall polysaccharides' extraction, as well as cell wall changes during processing and quality control of fruits and vegetables [23, 24]. FT-IR spectroscopy combined with principal component analysis (PCA) has proven to be very useful for the fast evaluation of cell wall polysaccharides' composition of pectic and hemicellulosic components derived from plant material when applied in the wavenumber region of 1,200 $800 \mathrm{~cm}^{-1}$ [23-27]. It was also proven to be useful for determining structural and compositional changes of cell walls during the habituation of bean callus cultures treated by dichlobenil [8] or as result of thermal processing of pears [24]. Moreover, FT-IR with PCA was applied to determine the degree of amidation and methylesterification of pectic polysaccharides in plant cell wall extracts, and developed models were shown to be very consistent [19-21, 27].

FT-IR most frequently analysis was performed on supernatant containing pectic and hemicellulosic extracts, for example, from olive pulp and sun-dried pear cell walls [23-25, 28]. However, the method has not been applied yet for the analysis of cell wall residues directly obtained after the extraction. Therefore, this paper will try to identify cell wall polysaccharides according to their occurrence in each residue of extraction by FT-IR spectroscopy. The aim of this study is the analysis of differences in composition among cell wall residues and among plant species (fruits and vegetables) using FT-IR spectroscopy in association with PCA. This paper proposes the identification of specific wavenumbers that could discriminate the different polysaccharide constituents of cell walls according to their FT-IR spectra within two specific regions: $1,800-1,200 \mathrm{~cm}^{-1}$ and $1,200-800 \mathrm{~cm}^{-1}$.
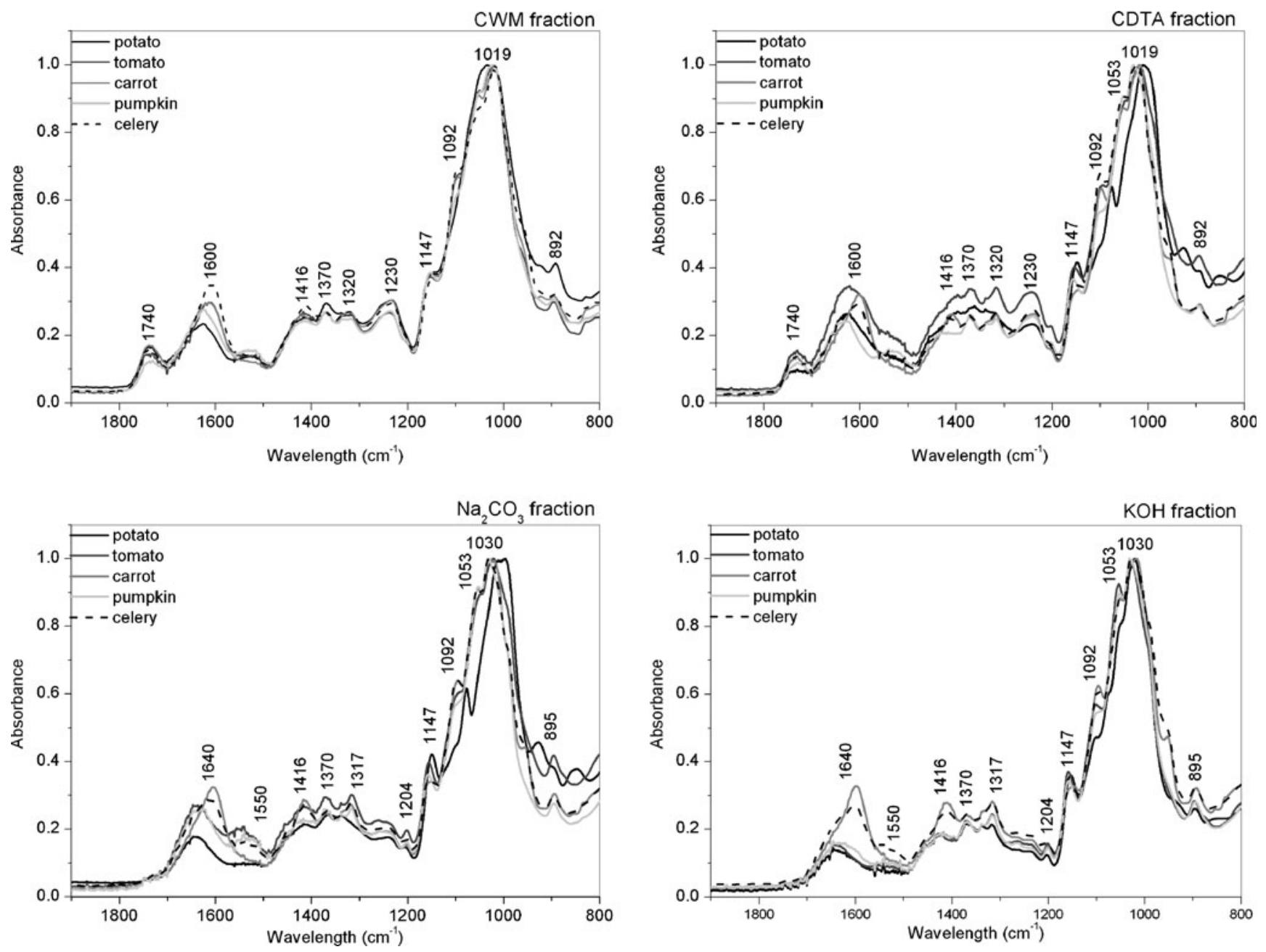

Fig. 2 FT-IR spectra in 2,000-650 $\mathrm{cm}^{-1}$ region of four residues after each step of extraction 


\section{Materials and Methods}

\section{Cell Wall Polysaccharide Extraction}

The parenchyma samples of five species: pumpkin (Curcurbita L. cv. Bambino), celery (Apium graveolens L. var. rapaceum Mill. cv. Edward), carrot (Daucus carota L. cv. Finezja), tomato (Lycopersicon esculentum Mill. cv. Plomien) and potato (Solanum tuberosum cv. Irga), which were purchased at a local grocery market, were used for preparation of cell wall material. Cell wall material (CWM) from the species was isolated using the modified hot alcohol insoluble solids method as proposed by Renard (2005) [29]. Briefly, the fresh slices of material were ground by several bursts of a kitchen processor (Zauberstab, ESGE, Hockenheim, Switzerland), then dropped in hot alcohol (ethanol $70 \%$, temperature approx $82-85{ }^{\circ} \mathrm{C}$ ) and left for $20 \mathrm{~min}$ of boiling. Then material was filtered through $65 \mathrm{G}$ paper filter and then washed successively in $70 \%$ and $96 \%$ ethanol until the test for sugar presence using the phenol-sulphuric method of Dubois et al. 1956 [30] was negative, and finally placed in acetone. The sample was vacuum dried.

The obtained cell walls were further subjected to fractionation using the method proposed by Redgwell et al. (2008)

Table 1 Comparison of FT-IR absorption bands for assignment of cellulose, pectin and xyloglucan obtained in present experiment (column a) with previous results from refs $[6,20,32-35]$ (column b). In column e, the residues of which spectra contains given frequency are denoted

\begin{tabular}{|c|c|c|c|c|}
\hline $\begin{array}{l}\text { a } \\
\text { Frequency range } \\
\text { (measured) }\end{array}$ & $\begin{array}{l}\mathrm{b} \\
\text { Frequency range } \\
\text { (literature) }\end{array}$ & $\begin{array}{l}\mathrm{c} \\
\text { Assignment }\end{array}$ & $\begin{array}{l}\mathrm{d} \\
\text { Origin }\end{array}$ & $\begin{array}{l}\mathrm{e} \\
\text { Comment }\end{array}$ \\
\hline $1740-1730(\mathrm{P})$ & $1745-1740$ & $\begin{array}{l}\mathrm{C}=\mathrm{O} \text { stretching vibration of } \\
\text { alkyl ester }\end{array}$ & Pectin & CWM and CDTA residue \\
\hline- & 1650 & Amid I C-N stretching & Proteins & Mainly in $\mathrm{Na}_{2} \mathrm{CO}_{3}$ residue \\
\hline- & 1640 & $\mathrm{H}-\mathrm{O}-\mathrm{H}$ bending vibration & Absorbed water & Mainly in $\mathrm{Na}_{2} \mathrm{CO}_{3}$ residue \\
\hline $1600(\mathrm{P})$ & $1630-1600$ & $\mathrm{COO}^{-}$antisymmetric stretching & $\begin{array}{l}\text { Polygalacturonic acid, carboxylate } \\
\text { (pectin ester group) }\end{array}$ & Mainly CWM and CDTA residue \\
\hline- & 1550 & Amid II N-H deformation & Proteins & \\
\hline $1428(\mathrm{C})$ & 1426 & $\mathrm{CH}_{2}$ symmetric bending & Cellulose & $\begin{array}{l}\text { All residue, most intensive } \mathrm{KOH} \\
\text { residue }\end{array}$ \\
\hline $1410(\mathrm{P})$ & 1400 & $\mathrm{COO}^{-}$symmetric stretching & Carboxylate (pectin ester group) & CWM and CDTA residue \\
\hline $1362(\mathrm{XG}, \mathrm{C})$ & 1370 & $\mathrm{CH}_{2}$ bending & Xyloglucan, Cellulose & All residues \\
\hline $1330(\mathrm{P})$ & 1320 & Ring vibration & Pectin & CWM and CDTA residue \\
\hline $1313(\mathrm{C})$ & 1317 & $\mathrm{CH}_{2}$ symmetric bending & Cellulose & $\mathrm{KOH}$ residue \\
\hline $1268-1230(\mathrm{P})$ & 1243 & $\mathrm{C}-\mathrm{O}$ stretching & Pectin & CWM and CDTA residue \\
\hline $1160(\mathrm{C})$ & 1160 & $\mathrm{O}-\mathrm{C}-\mathrm{O}$ asymmetric stretching & Cellulose (glycosidic link) & All residues \\
\hline $1143(\mathrm{P})$ & 1146 & $\mathrm{O}-\mathrm{C}-\mathrm{O}$ asymmetric stretching & Pectin (glycosidic link) & All residues \\
\hline $1147(\mathrm{XG})$ & 1130 & $\mathrm{O}-\mathrm{C}-\mathrm{O}$ asymmetric stretching & Xyloglucan (glycosidic link) & None \\
\hline $1103(\mathrm{C})$ & 1115 & $\mathrm{C}-\mathrm{O}$ stretching, $\mathrm{C}-\mathrm{C}$ stretching & Cellulose (C2-O2) & $\mathrm{KOH}$ residue \\
\hline $1093(\mathrm{P})$ & 1100 & $\mathrm{C}-\mathrm{O}$ stretching, $\mathrm{C}-\mathrm{C}$ stretching & Pectin (ring) & None \\
\hline $1071(\mathrm{XG})$ & 1075 & $\mathrm{C}-\mathrm{O}$ stretching, $\mathrm{C}-\mathrm{C}$ stretching & Xyloglucan (ring) & None \\
\hline Absence & 1042 & $\mathrm{C}-\mathrm{O}$ stretching, $\mathrm{C}-\mathrm{C}$ stretching & Xyloglucan (ring) & None \\
\hline $1030(\mathrm{C})$ & 1030 & $\mathrm{C}-\mathrm{O}$ stretching, $\mathrm{C}-\mathrm{C}$ stretching & Cellulose $\left(\mathrm{C} 6-\mathrm{H}_{2}-\mathrm{O} 6\right)$ & \\
\hline $1014(\mathrm{P})$ & 1019 & $\mathrm{C}-\mathrm{O}$ stretching, $\mathrm{C}-\mathrm{C}$ stretching & Pectin (C2-C3, C2-O2, C1-O1) & $\mathrm{KOH}$ fraction \\
\hline $1000(\mathrm{C})$ & 1000 & $\mathrm{C}-\mathrm{O}$ stretching, $\mathrm{C}-\mathrm{C}$ stretching & Cellulose $\left(\mathrm{C} 6-\mathrm{H}_{2}-\mathrm{O} 6\right)$ & $\mathrm{Na}_{2} \mathrm{CO}_{3}$ residue (potato) \\
\hline $954(\mathrm{P})$ & 960 & CO bending & Pectin & None \\
\hline $941(\mathrm{XG})$ & 944 & Ring vibration & Xyloglucan & None \\
\hline 899 (C), 893 (XG) & 895 & $\mathrm{C} 1-\mathrm{H}$ bending & $\begin{array}{l}\text { Xyloglucan, Cellulose } \\
\text { ( } \beta \text {-anomeric link) }\end{array}$ & All residues \\
\hline $832(\mathrm{P})$ & 833 & Ring vibration & Pectin & CDTA and $\mathrm{NA}_{2} \mathrm{CO}_{3}$ residue (potato) \\
\hline $\begin{array}{l}\text { Bands not assigned } \\
1416\end{array}$ & $\mathrm{XG}$ & & & \\
\hline 1204 & C, XG & & & \\
\hline 1053 & $\mathrm{C}$ & & & \\
\hline 1019 & $\mathrm{XG}$ & & & \\
\hline 888 & $\mathrm{P}$ & & & \\
\hline
\end{tabular}


[31] with some modifications. The CWM (450 mg) was stirred in $0.1 \mathrm{M}$ trans-1,2-diaminocyclohexane-N,N, $\mathrm{N}^{\prime}, \mathrm{N}^{\prime}$-tetraacetic acid, (CDTA, $\mathrm{pH} 6.5,25 \mathrm{~mL}$ ) at $25^{\circ} \mathrm{C}$ for $6 \mathrm{~h}$. Then it was filtered and the residue disolved in $0.05 \mathrm{M}$ CDTA (pH $6.5,25 \mathrm{~mL}$ ), stirred at $25^{\circ} \mathrm{C}$ for $2 \mathrm{~h}$ and again filtered. The residue of this step has been called CDTA residue.

Then, the CDTA residue was stirred in $0.05 \mathrm{M}$ sodium carbonate $\left(\mathrm{Na}_{2} \mathrm{CO}_{3}\right)(30 \mathrm{~mL})$ with the addition of $20 \mathrm{mM}$ sodium borohydrite $\left(\mathrm{NaBH}_{4}\right)$ for approximately $20 \mathrm{~h}$ at $1{ }^{\circ} \mathrm{C}$, filtered, and again stirred for $2 \mathrm{~h}$ at $20^{\circ} \mathrm{C}$. The residue of this step has been called $\mathrm{Na}_{2} \mathrm{CO}_{3}$ residue.

Then, the $\mathrm{Na}_{2} \mathrm{CO}_{3}$ residue (depectinated cell walls) was stirred firstly in $12 \mathrm{~mL}$ of $0.5 \mathrm{M}$ potassium hydroxide $(\mathrm{KOH})$ and then in $12 \mathrm{~mL}$ of $1 \mathrm{M} \mathrm{KOH}$, both with an addition of $20 \mathrm{mM}$ sodium borohydride $\left(\mathrm{NaBH}_{4}\right)$ each for $2 \mathrm{~h}$ at $20^{\circ} \mathrm{C}$ every time. The residue of this step has been called $\mathrm{KOH}$ residue.

All $\mathrm{KOH}$ residues from tissue were rinsed several times in deionised water and finally stirred in deionised water all night. At all stages of filtration a nylon filter (Millipore, pore size $11 \mu \mathrm{m}$ ) was used. At every step of extraction lyophilization of each residue was performed and lyophilized material was weighted. The steps of extraction are presented in Fig. 1.
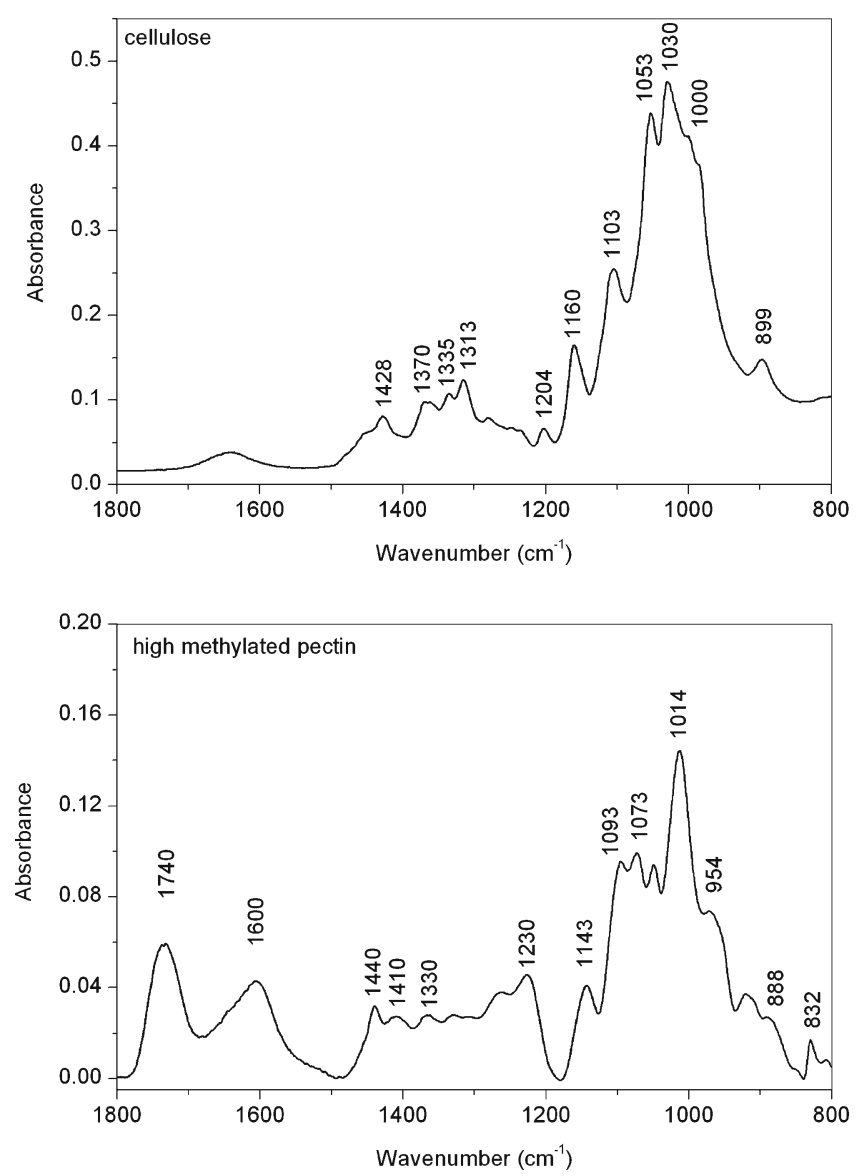

All chemicals used for extraction were purchased from Sigma Aldrich and were used without further purification.

Additionally, to obtain exemplary infrared spectra of pectins, hemicelluloses and cellulose the following commercially available compounds were utilized: high methylated (degree of methylation $80 \%$ ) and low methylated (degree of methylation $30 \%$ ) pectins (Herbstreit and Fox, Neuenbürg, Germany), microcrystalline cellulose (powder, particle size $\sim 20 \mu \mathrm{m}$, Sigma Aldrich) and xyloglucan (tamarind, purity $>95 \%$, Megazyme, Bray, Ireland) as the one of the most common hemicelluloses occurring in fruits and vegetables.

\section{FT-IR Spectroscopy}

FT-IR spectra were collected with the use of a Nicolet 6700 FT-IR spectrometer (Thermo Scientific, Waltham, MA, USA) with the Smart iTR ATR sampling accessory. Each cell wall polysaccharide residue was applied on ATR as powder. The spectra were collected over the range 4,000$650 \mathrm{~cm}^{-1}$. For each material, five samples under the same conditions were examined. For each sample, 200 scans were averaged with a spectral resolution of $4 \mathrm{~cm}^{-1}$. Then for a given material, a final average spectrum was calculated.
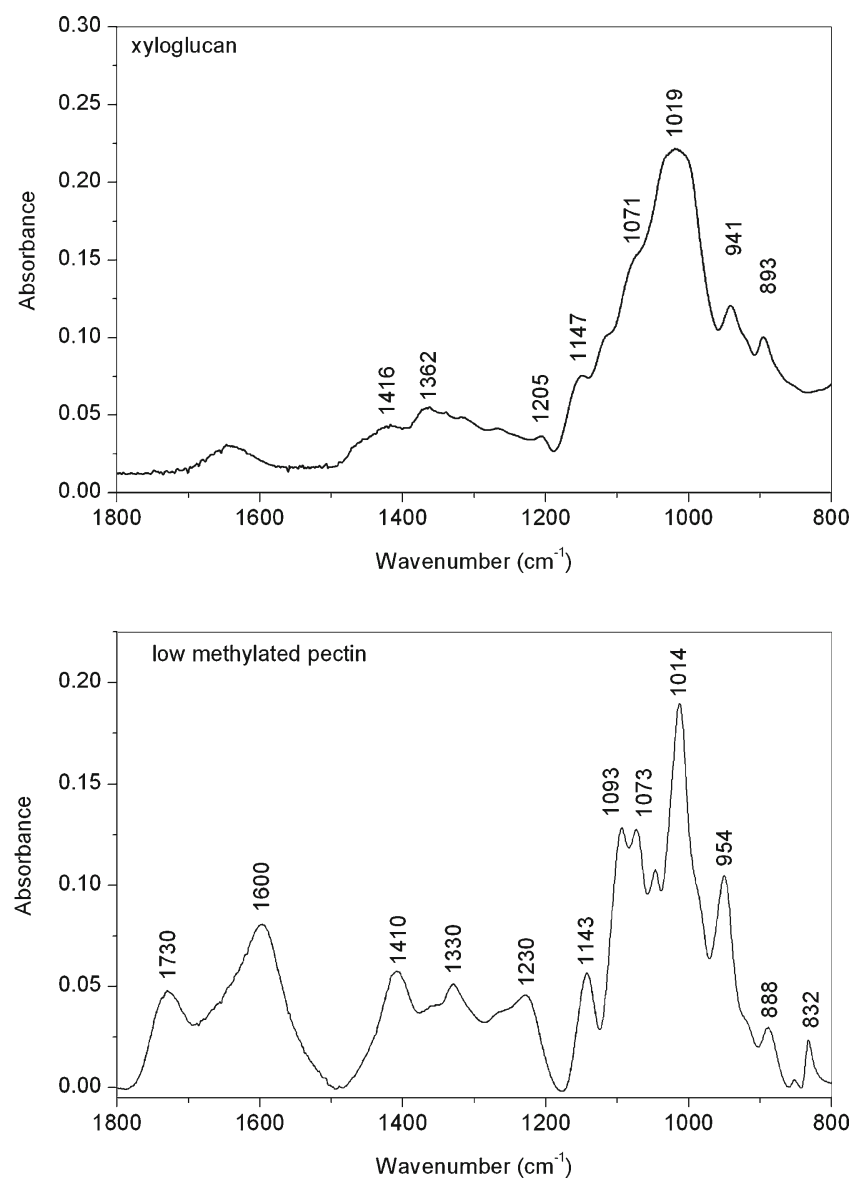

Fig. 3 FT IR spectra of high- and low-methylated pectins, cellulose and xyloglucan in the range of 1,800-650 $\mathrm{cm}^{-1}$ 
Baseline corrections were obtained using Omnic Software (Thermo Scientific).

\section{Pectin Content}

The chemical analysis of pectin content in the CDTA and $\mathrm{Na}_{2} \mathrm{CO}_{3}$ supernatant was performed with Automated Wet Chemistry Analyser also known as a Continuous Flow Analyser (San ++, Skalar Analytical, The Netherlands). This is an automated procedure for colorimetric determination of galacturonic acid based on total decomposition of pectin (hydrolysis with sulfuric acid) sample in acidic medium. The obtained products are transformed to furfuric derivatives, which when reacting with 3-phenyl phenol form a coloured dye, which is measured at $530 \mathrm{~nm}$. The pectin content is expressed as galcturonic acid content in the dry mass of cell wall material $(\mathrm{mg} / \mathrm{g})$.

\section{Principal Component Analysis}

Principal component analysis (PCA) is one of the most commonly used chemometric methods for data reduction and exploratory analysis of high-dimensional data sets. The main goal of PCA is to obtain a small set of principal components (PC) that explain the most variability on these data sets. PCA creates a new sub-space defined by PCs, easier to interpret than original data. It usually allows the recognition and highlighting of characteristics and their correlation to physico-chemical properties of the sample. This method is especially useful in the interpretation of FT-IR spectra, which show band diversity and complication depending on the source of the sample. The Unscrambler 10.1 (Camo Software AS., Norway) was used for performing PCA. Each wavelength of FT-IR was treated as variable and they were weighted by dividing by standard deviation.

\section{Result and Discussion}

\section{FT-IR Spectra}

Figure 2 presents the spectra of investigated residues of fruits and vegetables after each step of extraction in the range of $1,800-650 \mathrm{~cm}^{-1}$. These spectra were normalized to 1.0 at $1,020 \mathrm{~cm}^{-1}$ (C-O stretching vibration). The analysis of FT-IR spectra showed that each particular polysaccharide has a maximum of specific bands in the region 1,800 $800 \mathrm{~cm}^{-1}$ that are presented in Table 1. Additionally, there is in Table 1 comparison of infrared band assignments for cell wall polysaccharides found in literature as well as obtained in this experiment from commercially available
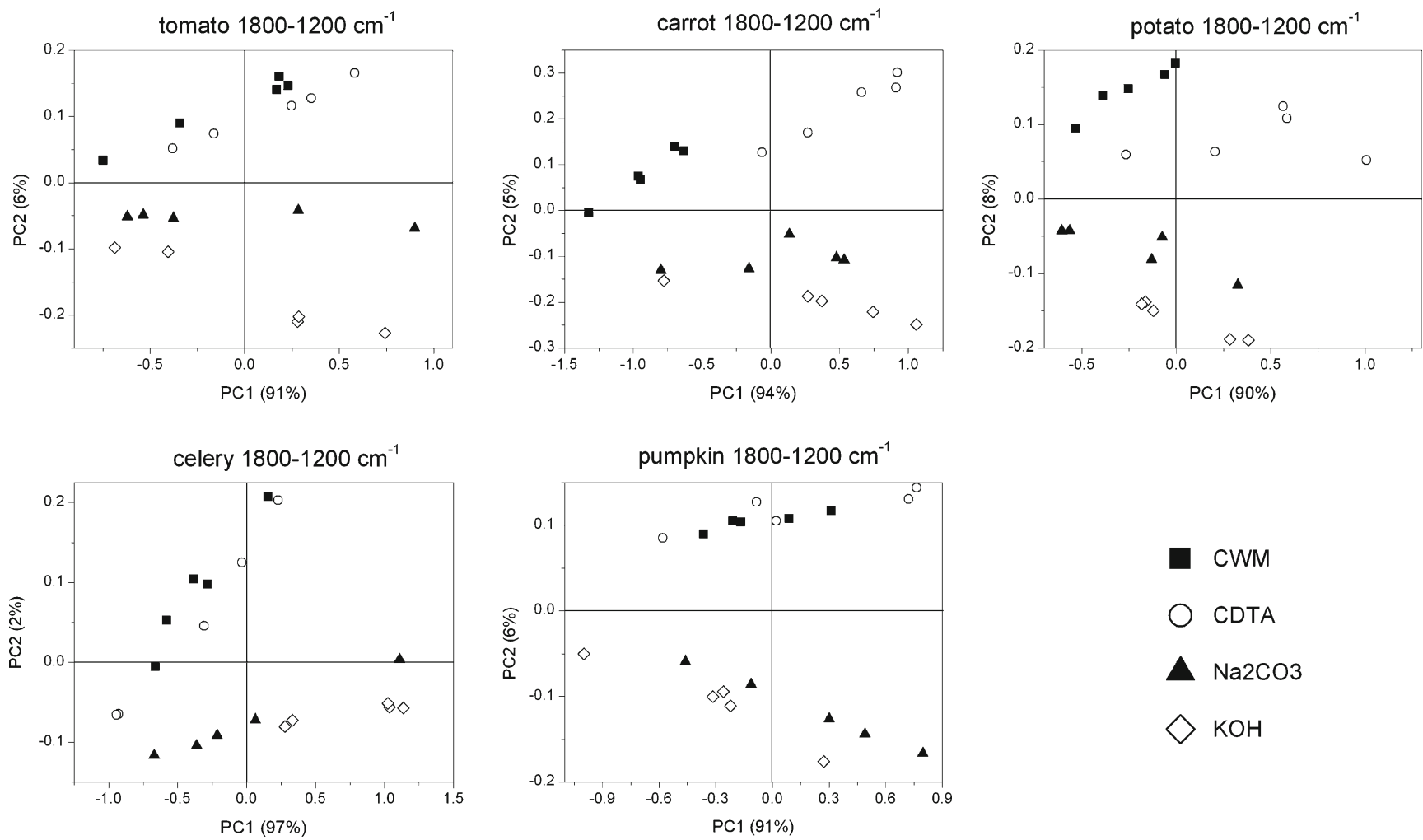

Fig. 4 PCA scores scatter plots of tomato, potato, carrot, celery and pumpkin cell wall FT-IR spectra in the $1,800-1,200 \mathrm{~cm}^{-1}$ region after sequential extraction of pectins and hemicelluloses 
polysacchrides. In the case of plant cell wall, polysaccharides are bonded with each other, therefore the shift of bands can be observed. The spectra in this region are characterized by strong absorption bands for specific wavenumbers, which could be assigned to pectic, hemicellulosic and cellulosic polysaccharides (Fig. 2) [32, 33]. Figure 3 depicts FT-IR spectra of pure plant cell wall polysaccharides.

The spectra of CWM and CDTA residues have very similar bands denoting pectins at: 1740, 1600, 1230, 1019, xyloglucan: 1370,1147 and cellulose $895 \mathrm{~cm}^{-1}$. However, some bands are sharper and more intensive if CDTA is compared to $\mathrm{CWM}$. For the $\mathrm{Na}_{2} \mathrm{CO}_{3}$ residue, the spectra bands, denoting xyloglucan and cellulose, become more visible at 1147 (XG) and $1030(\mathrm{C}) \mathrm{cm}^{-1}$ (Table 1). These bands were probably masked in CDTA and CWM by bands corresponding to pectins. The $\mathrm{KOH}$ residue consists of mainly cellulose, but also branched pectins and hemicelluloses, which are usually difficult to remove [34]. The infrared spectrum bands characteristic for cellulose are at $1,370,1,317 \mathrm{~cm}^{-1}$ (which are the sharpest for $\mathrm{KOH}$ spectra) and also at 1,097, 1,030 and
$1,000 \mathrm{~cm}^{-1}$. The band visible in $\mathrm{Na}_{2} \mathrm{CO}_{3}$ and $\mathrm{KOH}$ spectra at $1,640 \mathrm{~cm}^{-1}$ probably correspond to water in the samples $[35,36]$. Additionally, this band is affected by an amid I band centred at $1,650 \mathrm{~cm}^{-1}$, which indicates the presence of plant proteins. The presence of proteins is also confirmed by the existence of a band at $1,550 \mathrm{~cm}^{-1}$, which corresponds to amid II N-H vibration [20].

The main difference between spectra of CWM and CDTA residues, and $\mathrm{Na}_{2} \mathrm{CO}_{3}$ and $\mathrm{KOH}$ residues is revealed in the range of ester bands, which do not exist in the latter case. Significant differences can be noticed in the content of each polysaccharide and pectin esterification degree, as well as the intensity, shape and ratio of infrared bands situated around $1,740 \mathrm{~cm}^{-1}(\mathrm{C}=\mathrm{O}$, ester carbonyl groups stretching) and $1,630-1,600 \mathrm{~cm}^{-1}\left(\mathrm{COO}^{-}\right.$ carboxylate ion stretching band). Examples of FT-IR spectra of pectins with different esterification degree are shown in Fig. 3, where additionally cellulose and xyloglucan spectra are presented. The higher degree of esterification is reflected as the higher peak intensity and a

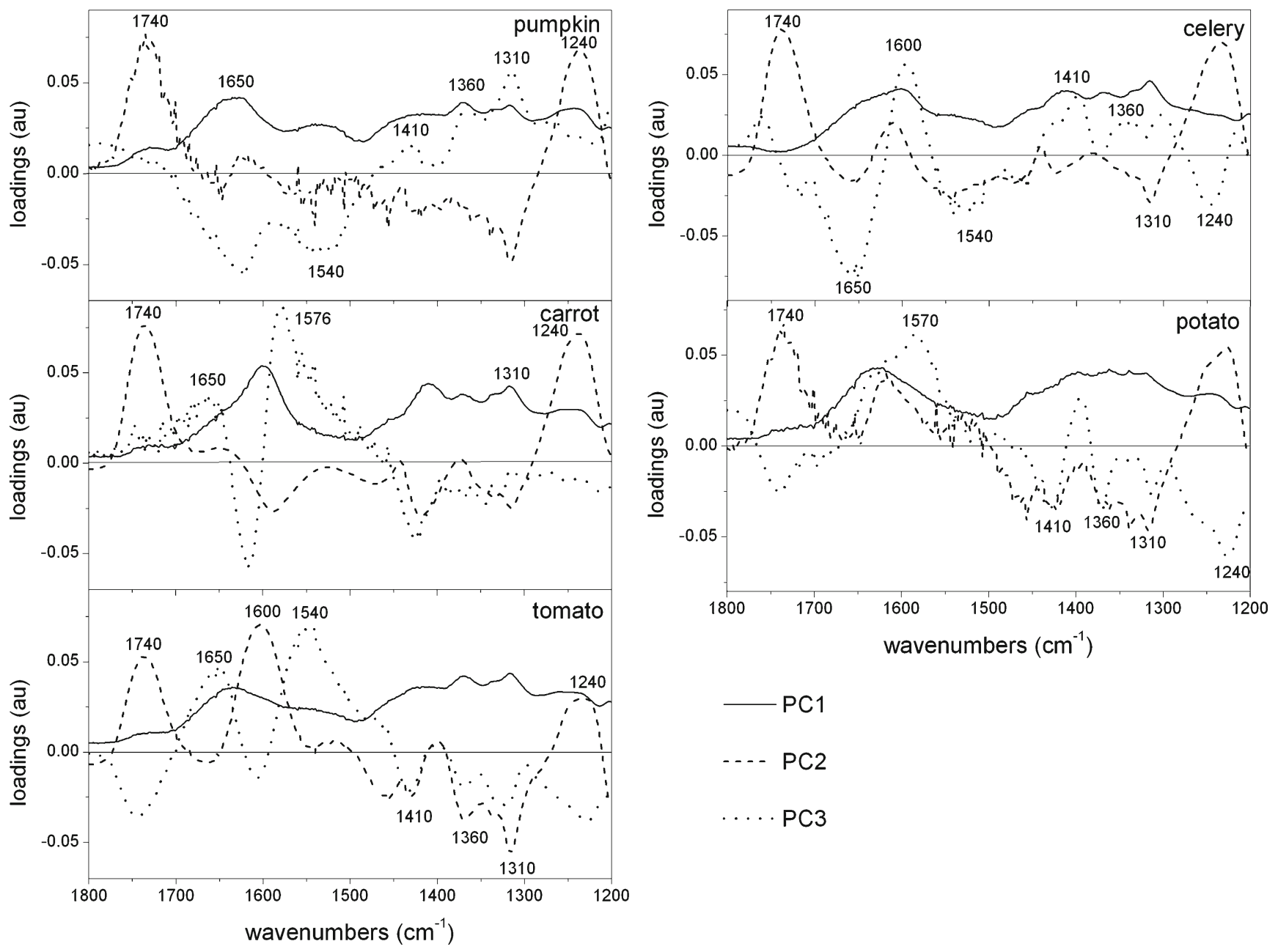

Fig. 5 PCA loadings plots (PC1, PC2 and PC3) of tomato, potato, carrot, celery and pumpkin cell wall FT-IR spectra in the $1,800-1,200 \mathrm{~cm}^{-1}$ region after sequential extraction of pectins and hemicelluloses 
peak shift to larger wavenumber band around $1,740 \mathrm{~cm}^{-1}$, and simultaneously, a decrease of the band situated at $1,600 \mathrm{~cm}^{-1}$ (Fig. 3). These spectra features have been previously used for evaluation of pectins' degree of esterification $[6,20,21]$, even though the consistency of the determination would be affected by water band (around $1,650 \mathrm{~cm}^{-1}$ ).

\section{PCA}

The most preferable region of FT-IR spectra for carbohydrates' analysis is $1,200-850 \mathrm{~cm}^{-1}$, which is not practically influenced by bands derived from proteins and water molecules, but the region of $1,800-1,200 \mathrm{~cm}^{-1}$ was also previously used for PCA $[23-26,28]$. The wavenumbers in the narrow region of $1,800-1,500 \mathrm{~cm}^{-1}$ are related to the carbonyl esters' and carboxylates' vibration, which reflects the pectic substances' content $[20,21]$. The region at $1,200-$ $850 \mathrm{~cm}^{-1}$ is dominated by stretching vibrations of $\mathrm{C}-\mathrm{O}, \mathrm{C}$ $-\mathrm{C}$, ring structures and deformation of $\mathrm{CH}_{2}$ groups' vibration characteristic for polysaccharides and is therefore useful in their identification [17]. However, the bands characteristic for each polysaccharide are located closely to each other, and in the case of a polisaccharides' mixture, this would cause problems with detection due to absorbance overlapping [5]. The common methods of polysaccharide extraction are imperfect hence in the very last residue, besides the cellulose, branched pectins and hemicelluloses are also present [34]. It can clearly be seen from a comparison of Figs. 2 and 3 that in the spectra of $\mathrm{KOH}$ residue, where only bands for pure cellulose should be present, in fact bands characteristic for pectic and hemicellulosic polysaccharides could also be found. This suggests implementing the PCA to both regions $1,800-1,200 \mathrm{~cm}^{-1}$ and $1,200-850 \mathrm{~cm}^{-1}$ to obtain the most complete information about investigated samples.

The PCA was carried out for 1) distinction cell wall residues within the studied species in terms of polysaccharide content and 2) revealing differences between species for the studied cell wall residues. The analysis were carried out within the two spectral ranges of FT-IR spectra. In each variant, three principal components were enough to explain differences among samples. For each residue/species sample, five FT-IR spectra were recorded which are replicates shown in PCA graphs.

\section{Discrimination of Cell Wall Residues}

1800-1200 $\mathrm{cm}^{-1}$ Region The scores scatter plots PC1 (explained above $90 \%$ of variability) $\times \mathrm{PC} 2$ (explained around 2-8 \% of variability) were used to obtain separation of each group in the $1,800-1,200 \mathrm{~cm}^{-1}$ region (Fig. 4). Although the major of variability was explained by $\mathrm{PC} 1$, it seems that $\mathrm{PC} 1$
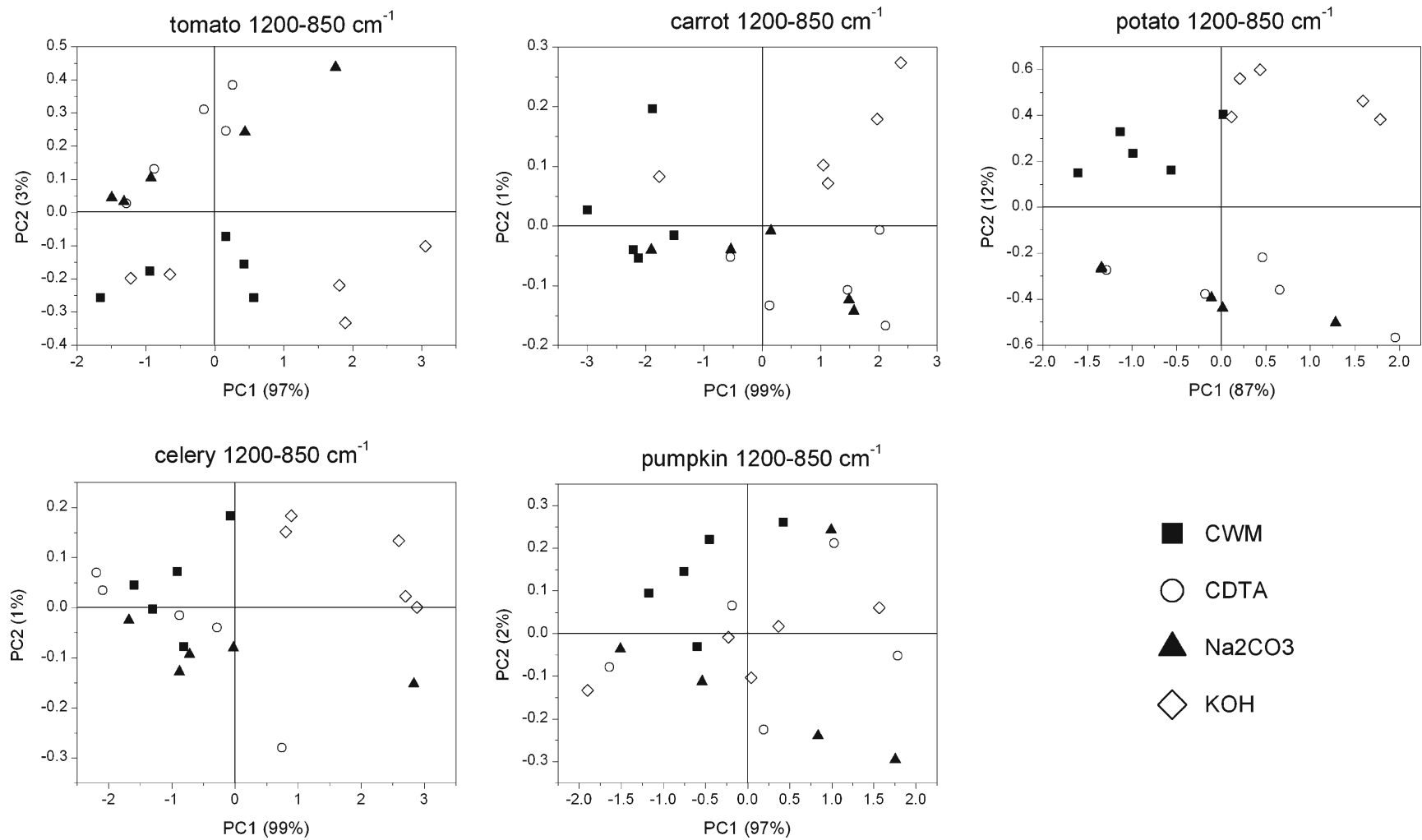

Fig. 6 PCA scores scatter plots of tomato, potato, carrot, celery and pumpkin cell wall FT-IR spectra in the $1,200-850 \mathrm{~cm}^{-1}$ region after sequential extraction of pectins and hemicelluloses 
only varies scores within each group, indicating that $\mathrm{PC} 1$ could reflect the standard deviation of recorded spectra. The scores scatter plot PC1 vs. PC2 (Fig. 4) indicates that the cell wall residues are grouped along the PC2 axis and scattered along the $\mathrm{PC} 1$ axis. The scores of residues abundant in pectic substances (CWM and CDTA) lay on the positive side of PC2 scores, while residues $\mathrm{Na}_{2} \mathrm{CO}_{3}$ and $\mathrm{KOH}$, which are rich in hemicelluloses and celluloses, were on the negative side of PC2 (Fig. 4). In Fig. 4 the tendency for the location of scores in four groups in a pattern going from positive to negative values of PC2:CWM, CDTA, $\mathrm{Na}_{2} \mathrm{CO}_{3}$ and $\mathrm{KOH}$ residue, which could reflect the subsequent steps of extraction, can be seen. Variable loadings for PC2 presented in Fig. 5 show peaks at $1,740,1,610$ and $1,230 \mathrm{~cm}^{-1}$ that are characteristic for the wavenumbers corresponding to pectic polysaccharides (Fig. 5). Whereas negative PC2 loading appeared for wavenumbers at 1,370 and $1,317 \mathrm{~cm}^{-1}$ characteristic for hemicellulosic and cellulosic polysaccharides, respectively.

The plot of $\mathrm{PC} 2 \times \mathrm{PC} 3$ (PC3 explains about $1 \%$ of variability), which is not shown in this paper, revealed less clear groupings and interpretation of the loadings was not as straightforward as it was in the case of the first two components (loading along PC3 are shown in Fig. 5). The significant bands of positive loading in PC3 were at 1,650 (carrot, tomato) and 1,550 (tomato) $\mathrm{cm}^{-1}$, which corresponds to amid I and amid II vibrations, respectively, and denotes the presence of proteins in plant cell wall material. However, in the case of pumpkin and celery, these wavelengths had negative impact on the scores. Also confusingly, positive values of loading were observed for wavenumbers at 1,410, 1,370 and $1,317 \mathrm{~cm}^{-1}$ (cellulose bands) for pumpkin and celery samples, whereas for potato, carrot and tomato samples, loadings for these wavelengths were negative (Fig. 5).

1200-850 $\mathrm{cm}^{-1}$ Region Considering the region of 1,200 $850 \mathrm{~cm}^{-1}$, the scores scatter plots PC1 (explained above $87 \%$ of variability) $\times \mathrm{PC} 2$ (explained up to $12 \%$ of variability), showed clear cell wall residue grouping only in the case of potato and tomato samples (Fig. 6). PC3 explains around $1 \%$ of variability (not schown). The PC1 explained the
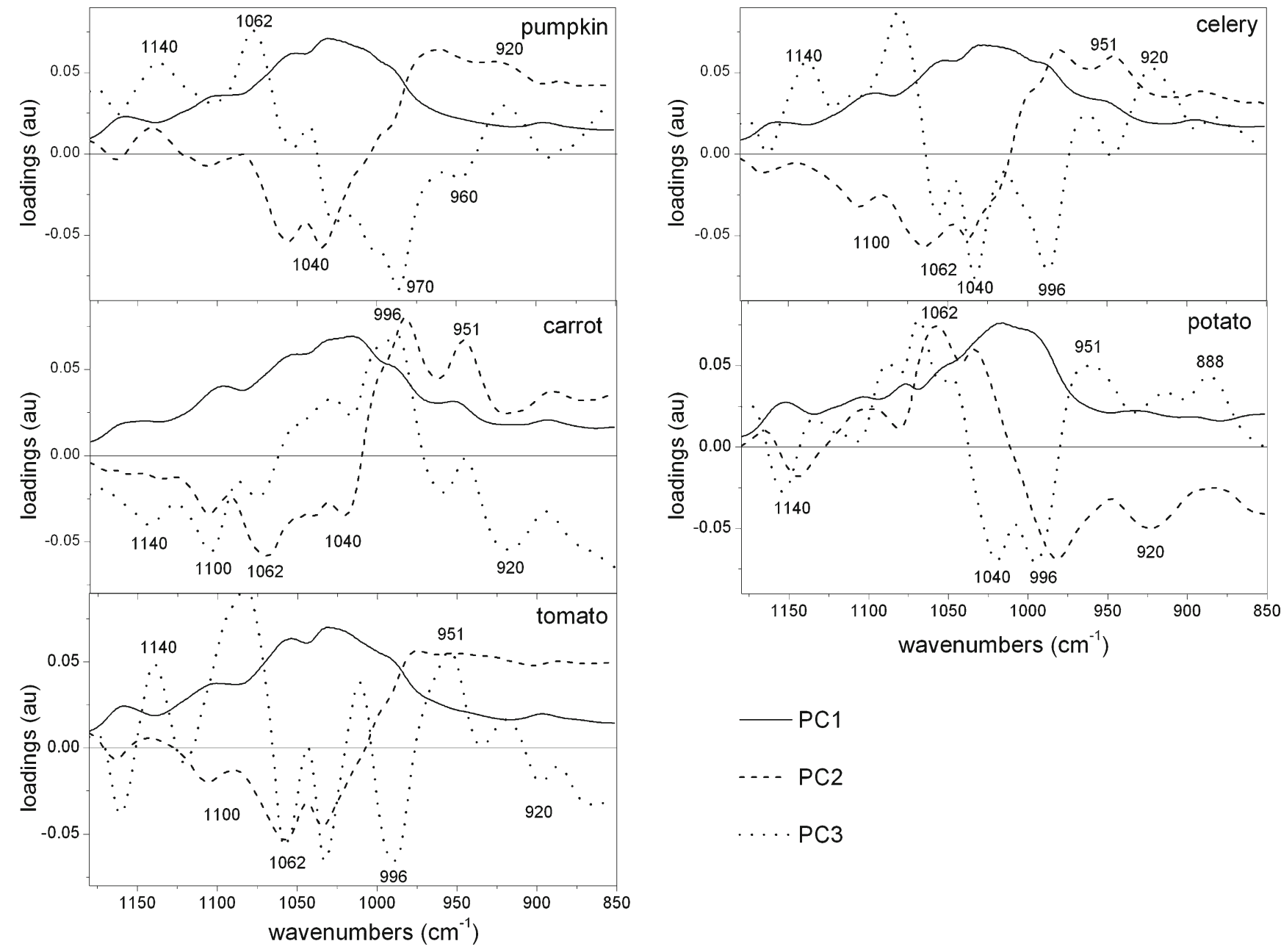

Fig. 7 PCA loadings plots (PC1, PC2 and PC3) of tomato, potato, carrot, celery and pumpkin cell wall FT-IR spectra in the $1,200-850 \mathrm{~cm}^{-1}$ region after sequential extraction of pectins and hemicelluloses 
majority of variability and its loadings had only positive values (Fig. 7), however, scores within groups are randomly scattered along PC1 axis. Common among species, significant bands on PC2 loading have positive influence (apart from potato samples) on scores around $970 \mathrm{~cm}^{-1}$ (pectins) and negative around $1,035 \mathrm{~cm}^{-1}$ (cellulose) (Fig. 7). While for PC3 loadings, the wavenumbers which positively influence the scores are around $1,070 \mathrm{~cm}^{-1}$, denoting xyloglucan, and around 1,140 and $960 \mathrm{~cm}^{-1}$ denoting pectins (apart from carrot samples). Loadings with negative values usually occur at 1,030 and $996 \mathrm{~cm}^{-1}$, which are close to wavenumber characteristics for cellulose vibration bands.

To summarize this part, the two bands analysed above suggest that for the each sample the region of 1,800$1,200 \mathrm{~cm}^{-1}$ discriminates cell wall residues. Each residue was well separated and scores varied the most significantly along the PC2. The loadings indicate that positive influence on scores have wavenumbers denoting pectins $(1,740,1,610$ and $1,240 \mathrm{~cm}^{-1}$ ) and negative on scores have wavenumbers denoting hemicelluloses and cellulose $(1,370$ and $1,317 \mathrm{~cm}^{-1}$, respectively). Therefore, residues with high content of pectins (CWM and CDTA) lie on the positive side of the PC2 axis and residues with only hemicellulose and cellulose content $\left(\mathrm{Na}_{2} \mathrm{CO}_{3}\right.$ and $\left.\mathrm{KOH}\right)$ lie on the negative side.

\section{Discrimination of Species}

1800-1200 $\mathrm{cm}^{-1}$ Region Similar to cell wall residue discrimination, the scores scatter plots $\mathrm{PC} 1 \times \mathrm{PC} 2$ and $\mathrm{PC} 2 \times \mathrm{PC} 3$ were used to separate the five investigated species.

The scores scatter plots PC1 (explained above $91 \%$ of variability, figure not shown) $\times \mathrm{PC} 2$ (explained around 4 $6 \%$ of variability) and $\mathrm{PC} 2 \times \mathrm{PC} 3$ (explained around $2 \%$ of variability) were used to obtain separation of each group, but only in the PC2 $\times \mathrm{PC} 3$ ( $3 \%$ of explained variability) plot was the grouping visible (Fig. 8). The PCA of CWM residue showed only a small grouping effect for species (Fig. 8). Only pumpkin, potato and carrot scores are grouped separately as scores for tomato and celery samples are mixed together. The component $\mathrm{PC} 1$ explains $92 \%$ of variability, however, its loadings took only positive values and scores were again scattered along this axis (figure not shown). Only the potato CWM sample lay on the negative side of the PC2 axis ( $5 \%$ of explained variability), the remaining
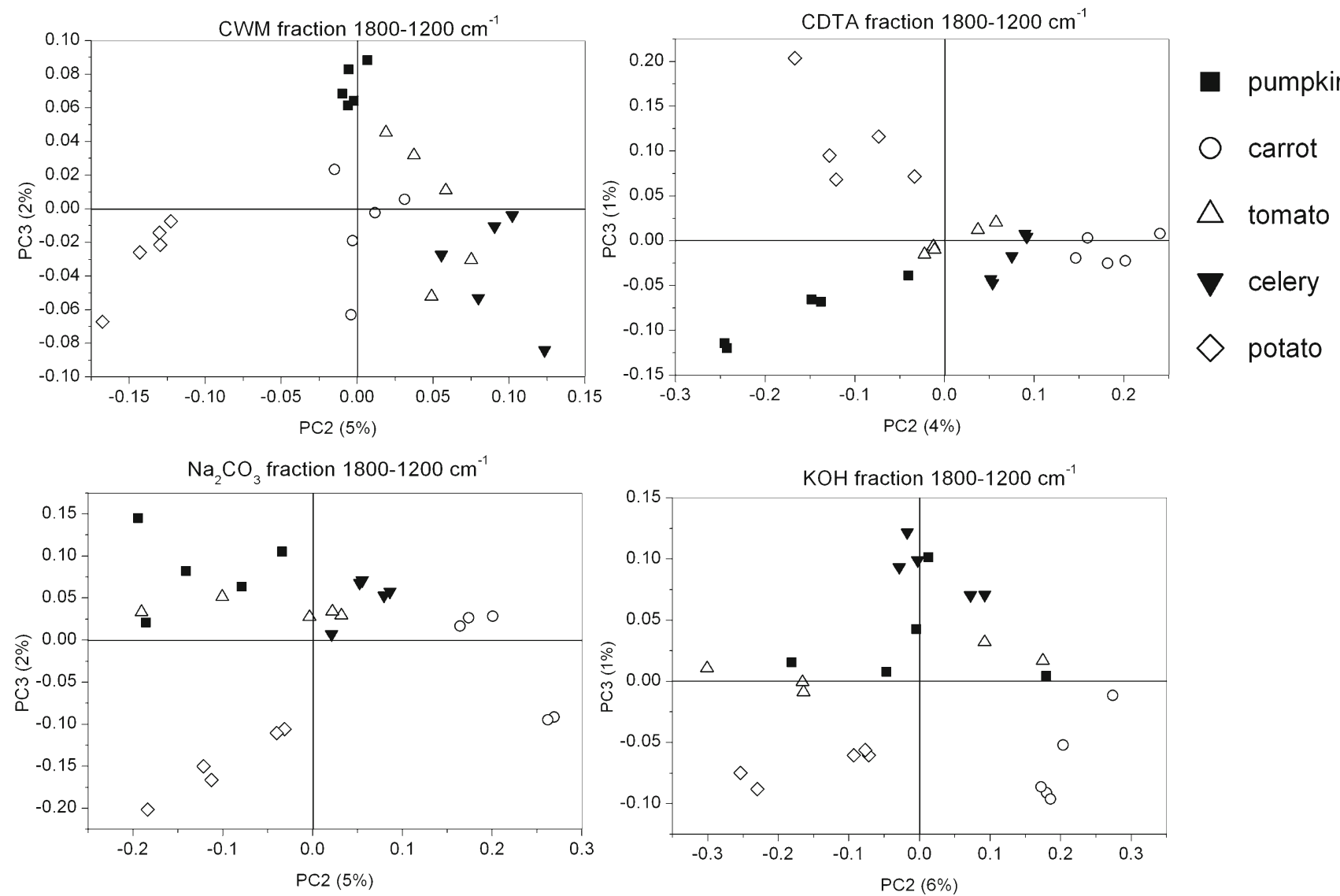

Fig. 8 PCA scores scatter plots of the FT-IR spectra of CWM, CDTA, $\mathrm{Na}_{2} \mathrm{CO}_{3}$ and $\mathrm{KOH}$ residue obtained by sequential extraction of tomato, potato, carrot, celery and pumpkin cell wall in the $1,800-1,200 \mathrm{~cm}^{-1}$ region 
samples lay on its positive side or oscillated around zero (Fig. 8). PC2 loading had only one significant positive maximum corresponding to the $1,600 \mathrm{~cm}^{-1}$, which denotes $\mathrm{COO}^{-}$ antisymmetric stretching of ester groups in pectins (Fig. 9). PC3 loadings took positive values around 1,650 and $1,550 \mathrm{~cm}^{-1}$, which corresponds to amid I and amid II infrared bands, respectively, and a negative value for $1,600 \mathrm{~cm}^{-1}$.

In the case of CDTA, the residue grouping effect of the studied species was more visible on both scatter plots $\mathrm{PC} 1 \times \mathrm{PC} 2$ (not shown) and $\mathrm{PC} 2 \times \mathrm{PC} 3$ (Fig. 8 ) with scores dispersed along the $\mathrm{PC} 1$ axis. The loadings in the case of PC2 obtained positive values at 1,740 and 1,600, 1,400 and $1,240 \mathrm{~cm}^{-1}$ corresponding to functional group vibrations in pectins (Fig. 9). The negative impact on the scores had wavelengths at 1,650, 1,550 (amid I and amid II), 1,430 and $1,360 \mathrm{~cm}^{-1}$ (cellulose vibration bands). In the case of PC3, a positive impact on scores corresponds to wavenumbers denoting vibration for cellulose: $1,360 \mathrm{~cm}^{-1}$ and pectins: $1,400 \mathrm{~cm}^{-1}$. Whereas negative impact on scores corresponds to wavenumbers: 1,740 and $1,240 \mathrm{~cm}^{-1}$ denoting vibration for pectins and wavenumber $1,550 \mathrm{~cm}^{-1}$ denoting vibration for amid II.

In $\mathrm{Na}_{2} \mathrm{CO}_{3}$ and $\mathrm{KOH}$ residues, the grouping of species was very similar, as well as loadings for specific components
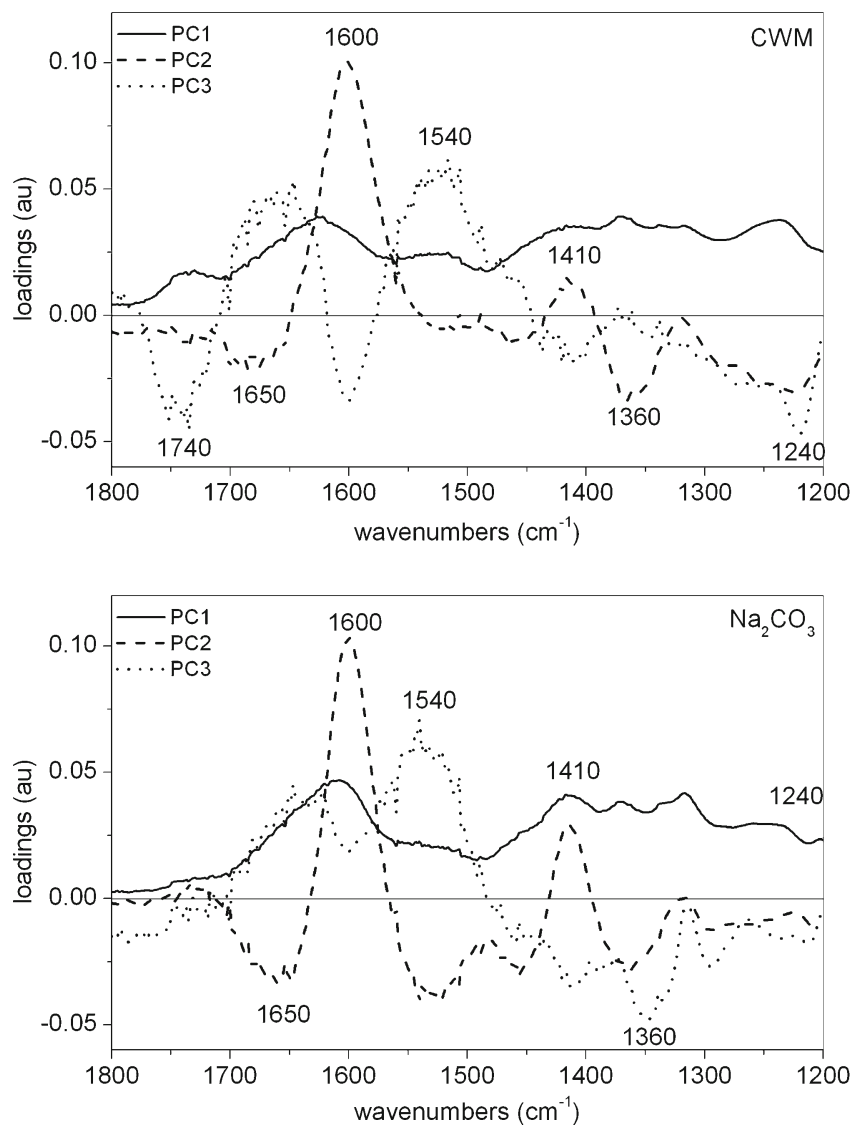

(Figs. 8 and 9). Significant values for PC1 appeared at 1,600 and $1,400 \mathrm{~cm}^{-1}$ which were characteristic for pectins, and $1,317 \mathrm{~cm}^{-1}$, which was characteristic for cellulose and was positive. There were in fact two loadings having positive impact on PC2 scores: strong around $1,600 \mathrm{~cm}^{-1}$ and smaller around $1,410 \mathrm{~cm}^{-1}$, both denoting pectins. The negative impact had values around 1,430 and $1,360 \mathrm{~cm}^{-1}$ which are characteristic for cellulose. For PC3 there were two strong positive values around 1,650 and $1,550 \mathrm{~cm}^{-1}$ (amid I and amid II bands) and two negative, 1,630 and 1,410 $\mathrm{cm}^{-1}$, typical for pectins and cellulose, respectively.

1200-850 $\mathrm{cm}^{-1}$ Region The scores scatter plots PC1 (explained above $93 \%$ of variability) $\times \mathrm{PC} 2$ (explained around $2-7 \%$ of variability) and $\mathrm{PC} 2 \times \mathrm{PC} 3$ (explained $1 \%$ of variability) were used to obtain separation of each group, but only in the $\mathrm{PC} 2 \times \mathrm{PC} 3$ plot was the grouping visible (Fig. 10). Similar to the previous analyses, scores were scattered along the PC1 axis and its loadings had only positive values. The smallest grouping effect was obtained in the case of CWM for this spectral region. The PC3 loading obtained for every four sets of variables (CWM, CDTA, $\mathrm{Na}_{2} \mathrm{CO}_{3}$ and $\mathrm{KOH}$ ) had significant positive value corresponding to $1,100 \mathrm{~cm}^{-1}$ (cellulose) and to $951 \mathrm{~cm}^{-1}$
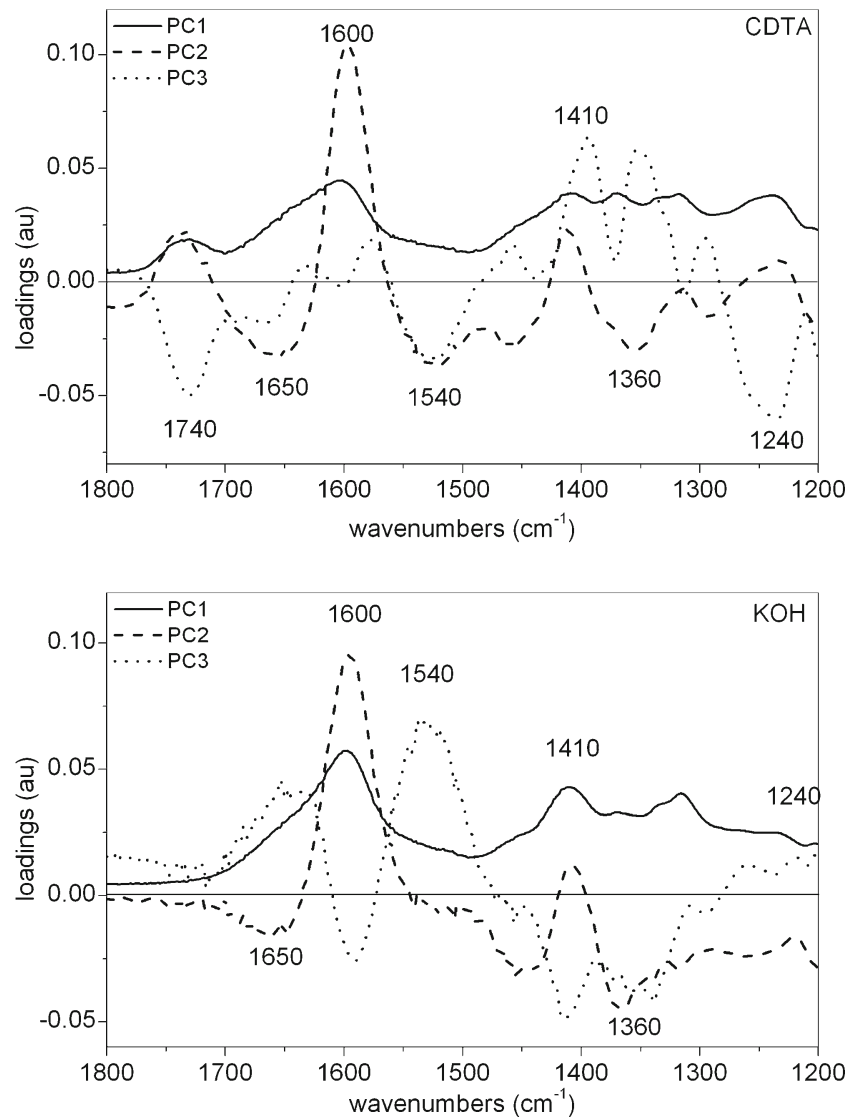

Fig. 9 PCA loadings plots (PC1, PC2 and PC3) of the FT-IR spectra of $\mathrm{CWM}, \mathrm{CDTA}, \mathrm{Na}_{2} \mathrm{CO}_{3}$ and $\mathrm{KOH}$ residues obtained by sequential extraction of tomato, potato, carrot, celery and pumpkin cell wall in the $1,800-1,200 \mathrm{~cm}^{-1}$ region 

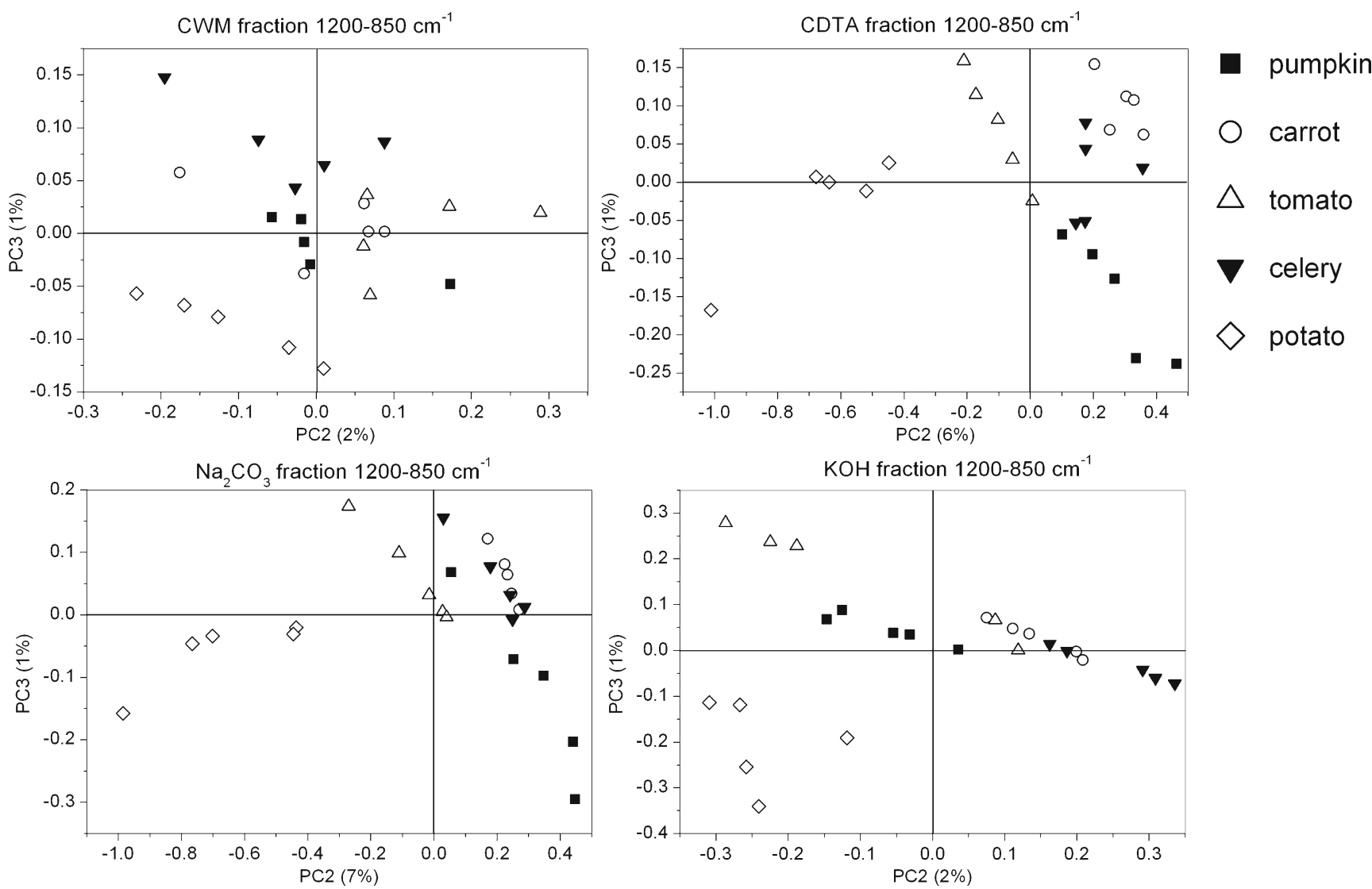

Fig. 10 PCA scores scatter plots of the FT-IR spectra of CWM, CDTA, $\mathrm{Na}_{2} \mathrm{CO}_{3}$ and $\mathrm{KOH}$ residue obtained by sequential extraction of tomato, potato, carrot, celery and pumpkin cell wall in the $1,200-850 \mathrm{~cm}^{-1}$ region

(pectins), but in the case of the second wavelength its value decreased to zero in the last residue (KOH) (Fig. 11). Negative influence had a wavenumber around 1,042 and $1,000 \mathrm{~cm}^{-1}$ (bands assigned to cellulose) for scores of CWM and CDTA residues. In the case of $\mathrm{Na}_{2} \mathrm{CO}_{3}$ and $\mathrm{KOH}$ residues, loadings for $1,042 \mathrm{~cm}^{-1}$ changed their values to positive, while for $1,000 \mathrm{~cm}^{-1}$, loadings remained negative.

PC2 loadings indicated that positive influence on CWM scores had values around 1,100 (cellulose), 1,070 and $1,020 \mathrm{~cm}^{-1}$ (xyloglucan), whereas negative at 970, 927 and $888 \mathrm{~cm}^{-1}$, which could be assigned to pectins. This pattern is similar for CDTA and $\mathrm{Na}_{2} \mathrm{CO}_{3}$ residues, but 1,020 is shifted to $1,030 \mathrm{~cm}^{-1}$ (band assigned to cellulose) and there is lack of a minimum around $888 \mathrm{~cm}^{-1}$. The biggest differences in loadings maximums and minimums were obtained for $\mathrm{KOH}$ residue PC3 loadings: positive influence was at $1,100 \mathrm{~cm}^{-1}$ (cellulose) and $951 \mathrm{~cm}^{-1}$ (pectins), and negative at $1,015 \mathrm{~cm}^{-1}$ (cellulose). The presence of a wavenumber which can be assigned to pectins or hemicellulose in $\mathrm{KOH}$ residue confirms that a part of the branched non-cellulosic polysaccharides are hard to remove from between the cellulose microfibrils [34].
Although a similar grouping effect for both of the chosen regions was obtained, a more pronounced grouping effect was achieved for the region $1,200-850 \mathrm{~cm}^{-1}$ and with use of PC2 and PC 3 components. The groups were probably created due to pectin and hemicellulose content. Generally, the primary cell wall of plants consists of $25 \%$ cellulose, $25 \%$ hemicellulose, $35 \%$ pectins, 1-8\% structural proteins, $1-$ $5 \%$ minerals and $2 \%$ phenolics compounds (\% of dry weight), but it must be remembered that these values can vary between species $[3,37]$. In Table 2 the results of pectin content in CDTA and $\mathrm{Na}_{2} \mathrm{CO}_{3}$ supernatants (as a galacturonic acid content $\mathrm{mg} / \mathrm{g}$ of dry mass of CWM residue) are shown. These values of pectin content are in good agreement with values obtained previously [38-42]. The most separated groups have been obtained for the potato sample. By comparing this result with Table 2 it can be concluded that potato contains the lowest content of ionically and covalently-bonded pectins among the samples. In the CWM residues, scores for other species are mixed together (not separated), however, for tomato, which is characterized by one of the biggest values of pectin content in the CDTA supernatant, all scores lie on the positive side of PC2 axis. Again for CDTA residue, scores $(\mathrm{PC} 2 \times \mathrm{PC} 3)$ for potato and 

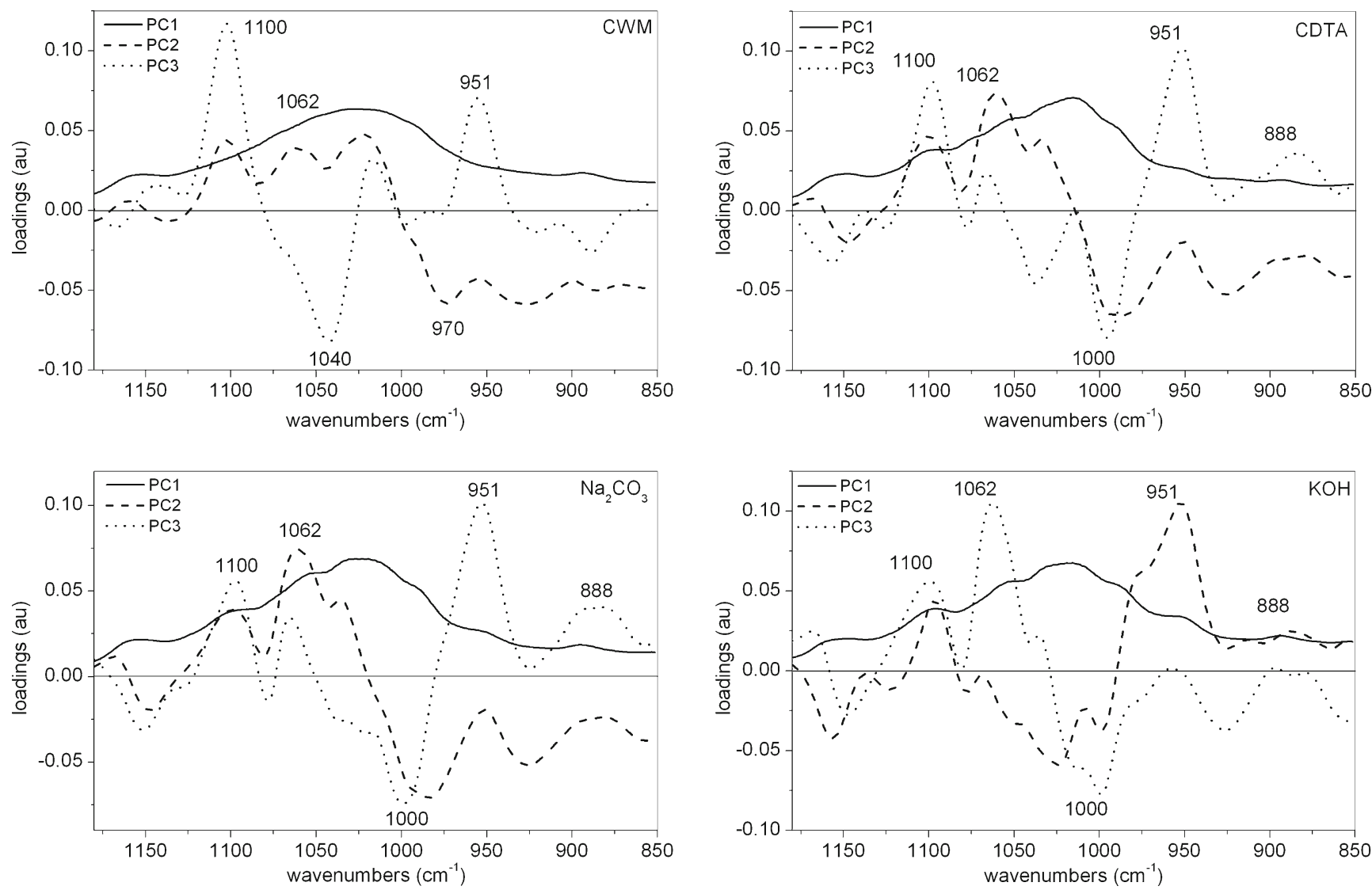

Fig. 11 PCA loadings plots (PC1, PC2 and PC3) of the FT-IR spectra of CWM, CDTA, $\mathrm{Na}_{2} \mathrm{CO}_{3}$ and $\mathrm{KOH}$ residues obtained by sequential extraction of tomato, potato, carrot, celery and pumpkin cell wall in the $1,200-800 \mathrm{~cm}^{-1}$ region

pumpkin, with the lowest content of covalently-bonded pectins, lie on the negative side of the PC3 axis. Scores for the remaining samples are arranged into groups, which are close to each other.

\section{Conclusion}

This study showed that discrimination between the cell wall residues of fruits and vegetables is possible with the use of FT-IR spectra in the regions $1,800-1,200 \mathrm{~cm}^{-1}$ and

Table 2 Pectin content in cell wall material from chosen vegetables as content of galacturonic acid (Gal A mg/g of dry mass of CWM). In parenthesis standard deviation

\begin{tabular}{lcc}
\hline Sample & \multicolumn{2}{c}{ Gal A content $(\mathrm{mg} / \mathrm{g}$ dry mass CWM $)$} \\
\cline { 2 - 3 } & $\mathrm{CDTA}$ and $\mathrm{Na}_{2} \mathrm{CO}_{3}$ supernatant & $\mathrm{Na}_{2} \mathrm{CO}_{3}$ supernatant \\
\hline Potato & $46,64( \pm 2,18)$ & $28,49( \pm 0,24)$ \\
Pumpkin & $102,95( \pm 0,72)$ & $20,40( \pm 0,36)$ \\
Carrot & $141,95( \pm 1,80)$ & $35,12( \pm 0,49)$ \\
Tomato & $253,04( \pm 2,44)$ & $56,16( \pm 0,82)$ \\
Celery root & $282,78( \pm 10,18)$ & $114,64( \pm 7,32)$ \\
\hline
\end{tabular}

$1,200-850 \mathrm{~cm}^{-1}$ analysed using the PCA method, however, better distinction was obtained for region $1,800-1,200 \mathrm{~cm}^{-1}$. The grouping is due to the pectin content and separation in PC2, and significant positive loadings of FT-IR absorbancies for residues distinction are: 1,740, 1,610 and $1,240 \mathrm{~cm}^{-1}$. The residues abundant in hemicelluloses and cellulose are separated in PC2 by the wavenumbers of 1,370 and $1,317 \mathrm{~cm}^{-} 1$, which influence the scores negatively. These results suggest that analysis of polysaccharides from cell walls can be successfully performed directly from subsequent residues.

The differences among species when all polysaccharide residues are considered are most highlighted when the PCA is implemented on the FT-IR region 1,200 $850 \mathrm{~cm}^{-1}$. The species mainly vary due to the content of ionically or covalently-bonded pectins (CWM and CDTA residues). However, species distinction by PCA was not as clear as in the case of discrimination of cell wall residues.

Acknowledgments The research was co-founded by National Centre of Science (research grant $\mathrm{nr}$ 2011/01/D/NZ9/02494). 
Open Access This article is distributed under the terms of the Creative Commons Attribution License which permits any use, distribution, and reproduction in any medium, provided the original author(s) and the source are credited.

\section{References}

1. C. Brett, K. Waldron, Physiology and Biochemistry of Plant Cell Wall, Topics in Plant Physiology (Unwin Hyman Ltd, London, 1990), pp. 4-22

2. N.C. Carpita, D.M. Gibeaut, Plant J. 3, 1-30 (1993)

3. L. Taiz, E. Zeiger, Plant Physiology, 3rd edn. (Sinauer Associates, Sunderland, 2002), pp. 314-337

4. P.R. Griffiths, J.A. De Haseth, Fourier Transform Infrared Spectrometry, 2nd edn. (Wiley, 2007), pp 321-362

5. M. Kačurakova, R.H. Wilson, Carbohydr. Pol. 44, 291-303 (2001)

6. A. Fellah, P. Anjukandi, M.R. Waterland, M.A.K. Williams, Carbohydr. Pol. 78, 847-853 (2009)

7. M. Černa, A.S. Barros, A. Nunes, S.M. Rocha, I. Delgadillo, J. Čopikova, M.A. Coimbra, Carbohydr. Pol. 51, 383-389 (2003)

8. A. Alonso-Simon, A.E. Encina, P. Garcia-Angulo, J.M. Alvarez, J.L. Acebes, Plant Sci. 167, 1273-1281 (2004)

9. E. Gümüskaya, M. Usta, H. Kirci, Polym. Degrad. Stab. 81, 559564 (2003)

10. C. Rondeau-Mouro, B. Bouchet, B.P. Pontoire, R.J. Mazoyer, A. Buléon, Carbohydr. Pol. 53, 241-252 (2003)

11. M. Szymańska-Chargot, J. Cybulska, A. Zdunek, Sensors 11, 5543-5560 (2011)

12. R.G. Zhbankov, S.P. Firsov, D.K. Buslov, N.A. Nikonenko, M.K. Marchewka, H. Ratajczak, J. Mol. Struct. 614, 117-125 (2002)

13. M.C. Jarvis, Food Hydrocoll. 25, 257-262 (2011)

14. A. Zykwinska, J.-F. Thibault, M.-C. Ralet, Carbohydr. Pol. 74, 957-961 (2008)

15. R.H. Atalla, J.M. Hackney, I. Uhlin, N.S. Thompson, Int. J. Biol. Macromol. 15, 109-112 (1993)

16. K.H. Caffall, D. Mohnen, Carbohydr. Res. 344, 1879-1900 (2009)

17. M. Kačurakova, P. Capek, V. Sasinkova, N. Wellner, A. Ebringerova, Carbohydr. Pol. 43, 195-203 (2000)

18. D. Mohnen, Curr. Opin. Plant Biol. 11, 266-277 (2008)

19. S.B. Engelsen, L. Norgaard, Carbohydr. Pol. 30, 9-24 (1996)
20. A.K. Chatjigakis, C. Pappas, N. Proxenia, O. Kalantzi, P. Rodis, M. Polissiou, Carbohydr. Pol. 37, 395-408 (1998)

21. R. Gnansambandam, A. Proctor, Food Chem. 68(327-332) (2000)

22. N. Wellner, M. Kačurakova, A. Malovikova, R.H. Wilson, P.S. Belton, Carbohydr. Res. 308, 123-131 (1998)

23. A.S. Barros, I. Mafra, D. Ferreira, S. Cardoso, A. Reis, J.A. Lopes da Silva, I. Delgadillo, D.N. Rutledge, M.A. Coimbra, Carbohydr. Pol. 50, 85-94 (2002)

24. D. Ferreira, A. Barros, M.A. Coimbra, I. Delgadillo, Carbohydr. Pol. 45, 175-182 (2001)

25. M.A. Coimbra, A. Barros, D.N. Rutledge, I. Delgadillo, Carbohydr. Res. 317, 145-154 (1999)

26. R. Hori, J. Sugiyama, Carbohydr. Pol. 52, 449-453 (2003)

27. H. Winning, N. Viereck, T. Salomonsen, J. Larsen, S.B. Engelsen, Carbohydr. Res. 344, 1833-1841 (2009)

28. M.A. Coimbra, A. Barros, M. Barros, D.N. Rutledge, I. Delgadillo, Carbohydr. Pol. 37, 241-248 (1998)

29. C.M.G.C. Renard, Carbohydr. Pol. 60, 512-522 (2005)

30. M. Dubois, K.A. Gilles, J.K. Hamilton, P.A. Rebers, F. Smith, Anal. Chem. 28, 350-356 (1956)

31. R.J. Redgwell, D. Curti, C. Gehin-Delval, Eur. Food Res. Technol. 227, 607-618 (2008)

32. M. Kačurakova, A.C. Smith, M.J. Gidley, R.H. Wilson, Carbohydr. Res. 337, 1145-1153 (2002)

33. C.F.B. Sene, M.C. McCann, R.H. Wilson, R. Grinter, Plant Physiol. 106, 1623-1631 (2004)

34. S.C. Fry, The Growing Plant Cell Wall: Chemical and Metabolic Analysis (The Blackburn Press. Longman Scientific \& Technical, UK, 1988), pp. 64-65

35. A. Synytsya, J. Čopikova, P. Matějka, V. Machovič, Carbohydr. Pol. 54, 97-106 (2003)

36. R.H. Wilson, A.C. Smith, M. Kačurakova, P.K. Saunders, N. Wellner, K.W. Waldron, Plant Physiol. 124, 397-405 (2000)

37. J. Cybulska, K. Konstankiewicz, A. Zdunek, K. Skrzypiec, Int. Agrophys. 24, 107-114 (2010)

38. K.C. Gross, S.J. Wallner, Plant Physiol. 63, 117-120 (1979)

39. K. Houben, R.P. Jolie, I. Fraye, A.M. Van Loey, M.E. Henddrickx, Carbohydr. Res. 346, 1105-1111 (2011)

40. M.C. Jarvis, M.A. Hall, D.R. Trelfall, J. Friend, Planta 152, 93 $100(1981)$

41. M.C. Jarvis, Planta 154, 344-346 (1982)

42. A. Kotcharian, H. Kunzek, G. Dongowski, Food Chem. 87, 231245 (2004) 